УДК 351.74

DOI https:/ / doi.org/10.32837 / yuv.v0i2.1707

\author{
А. Кубаєнко, \\ кандидат юридичних наук, доцент, \\ доцент кафедри організації судових, правоохоронних органів та адвокатури \\ Національного університету «Одеська юридична академія»
}

\title{
ВЗАЕМОДІї ПОЛІЦІї ТА СУСПІЛЬСТВА У СФЕРІ РЕАЛІЗАЦІї ПРАВООХОРОННОЇ ФУНКЦІї
}

Одним із пріоритетних завдань держави є створення сучасної та ефективної системи правоохоронних органів. Реорганізація органів Національної поліції зумовлена не тільки необхідністю вдосконалення професійної діяльності, а й зростаючою роллю поліції в житті суспільства. Зміна принципів діяльності поліції спрямована на підвищення якості роботи і професіоналізму поліцейських, на посилення довіри суспільства до діяльності правоохоронних органів.

Сучасні проблеми модернізації системи суспільних відносин не можуть бути вирішені без посилення уваги держави та інститутів громадянського суспільства до дотримання правопорядку, припинення різних видів злочинної діяльності та протиправної поведінки громадян. У суспільній свідомості продовжуються спроби сформувати образ держави, його органів управління і передусім поліції як органу насильства над громадянами. При цьому майже не звертається увага, що поліцейські є такими ж громадянами, з особистими мотиваціями, соціальними перевагами й орієнтаціями в суспільному розвитку, які властиві всім громадянам нашої держави.

Особливості взаємодії Національної поліції України з громадськістю у сфері реалізаціі правоохоронної функції досліджували такі науковці, як O.M. Бандурка, O.I. Беспалова, В.М. Галунько, В.Л. Грохольський, Д.П. Калаянов, О.В. Кожухар, А.Т. Комзюк, О.М. Коропатов, С.В. Медве- денко, Л.Р. Наливайко, О.С. Проневич, C.I. Субота, О.С. Юнін тощо.

Для вирішення питань підвищення репутації сучасного поліцейського, формування його позитивного іміджу великого значення набувають зв'язки з громадськістю (public relations - PR). Зв'язки з громадськістю регулюють взаємовідносини суспільства й організації, формують громадську думку. Стосовно силових структур PR слід розглядати як сукупність медійних і немедійних способів інформування населення про діяльність правоохоронних органів. Зв'язок із громадськістю є основним каналом інформування населення про стан правопорядку, інструментом формування суспільної довіри, засобом створення позитивного іміджу правоохоронців і можливістю отримання зворотного зв'язку з громадянами.

Ефективна взаємодія громадянського суспільства та держави під час реалізації правоохоронної функції може зблизити населення та владу, вирішити багато протиріч у соціальній та державно-правовій сферах. Тільки тісна взаємодія держави і громадянського суспільства в особі його інститутів допоможуть ефективному здійсненню правоохоронної функції держави в сучасних умовах.

Механізм партнерської взаємодії інститутів громадянського суспільства і держави у сфері реалізації правоохоронної функції передбачає наявність:

- суб'єктного складника (визначення кола суб'єктів, які беруть участь у реалізації правоохоронної функції держави); 
- нормативного складника - нормативно-правової бази - основи регулювання взаємовідносин інститутів держави і громадянського суспільства;

- функціонального складника напрямів спільної діяльності і організаційних форм взаємодії держави і громадянського суспільства (проведення форумів, здійснення громадського контролю).

Слушною є думка O.I. Беспалової, що суб'єкти реалізації правоохоронної функції держави можна умовно поділити на дві групи: державні та недержавні. Так, вона зазначає, що суб'єктами, які визначають державну політику України у правоохоронній сфері (загальними суб'єктами), є Президент України, Верховна Рада України та Кабінет Міністрів України. До числа суб'єктів, для яких здійснення правоохоронної діяльності є основним призначенням (спеціальних суб'єктів), належать правоохоронні органи, які безпосередньо займаються здійсненням правоохоронної діяльності, органи, уповноважені здійснювати оперативно-розшукову діяльність, а також судові органи як безпосередні суб'єкти реалізації правоохоронної функції держави.

Недержавними суб'єктами реалізації правоохоронної функції держави $€$ : органи місцевого самоврядування, інституції громадянського суспільства (наприклад, громадські організації та політичні партії, громадські консультативні ради, засоби масової інформаціï тощо) та інші суб'єкти (зокрема, адвокатура, нотаріат, законні представники, громадські експерти, аудитори тощо). Доцільність включення наведених вище суб'єктів до числа суб'єктів реалізації правоохоронної функції держави є беззаперечною, оскільки вони, не здійснюючи безпосередньо правоохоронну діяльність, забезпечують правозахисний компонент, чим сприяють іï належній реалізації іншими суб'єктами [1, с. 62].

O.C. Проневич уважає, що нова українська поліція має забезпечувати «публічну безпеку на локальному рівні» і вирішувати покладені на неї завдання у тісній взаємодії з населенням шляхом реалізації моделі Community Policing («служіння суспільству»). При цьому О.С. Проневич окремо підкреслює, що поліцейські структури мають надавати поліцейські послуги територіальній громаді конкретного локального рівня. I саме члени територіальної громади $€$ споживачем і основним суб'єктом оцінювання ефективності діяльності поліції [2, с. 642].

Схожої точки зору щодо оптимальної моделі функціонування нової украінської поліціі та взаємодіi іiі з громадянським суспільством дотримується О.С. Юнін. На думку науковця, поліція являє собою комплексну багаторівневу систему 3 організаційно і функціонально розгалуженою досить відособленою структурою [3, с. 60]. I на сучасному етапі розвитку правової держави і громадянського суспільства в Україні одним із напрямів діяльності поліції є соціальна функція.

Основу партнерської моделі взаємовідносин суб'єкта здійснення правоохоронної функції держави - поліції та інститутів громадянського суспільства становить довіра громадян до державних органів. Спираючись на співпрацю 3 інститутами громадянського суспільства, поліція здійснює правоохоронну діяльність, виконуючи своє головне призначення - служить суспільству. Основною передумовою партнерства поліції і громадянського суспільства є залучення громадян у процеси забезпечення публічної безпеки та порядку. За партнерської моделі населення не тільки безпосередньо бере участь в охороні правопорядку, а й своєчасно інформує поліцію про всі ситуації, які можуть загрожувати людям, що, своєю чергою, підвищує результативність діяльності поліції. В умовах такої взаємодії поліція є більш доступною для населення, краще реагує на проблеми громадян, частіше залучає і мобілізує населення для виконання завдань з охорони пра- 
вопорядку. Ефективність здійснення правоохоронної функції держави багато в чому залежить від взаємодії поліції і суспільства [4, с. 244].

Партнерська модель взаємовідносин органів державної влади та інститутів громадянського суспільства у сфері реалізації правоохоронної функції закріплена у багатьох міжнародних і національних нормативно-правових актах.

Кодекс поведінки службовців органів правопорядку, затверджений Резолюцією Генеральної Асамблеї ООН № 34/169 від 17 грудня 1979 р. [5], а також прийняті ООН для закріплення цього документа «Керівні принципи для ефективного здійснення Кодексу поведінки посадових осіб з підтримання правопорядку» (1989р.) [6] були взяті за основу під час вироблення норм поведінки працівників правоохоронних органів багатьох країн. Вимоги до поведінки і функцій працівників поліції, викладені в Кодексі, підкреслюють взаємозв'язок моральних і правових регуляторів у системі соціальних норм, покладених в основу професійної діяльності поліції. Необхідність захисту прав і свобод людини, недопущення свавілля з боку посадових осіб в їхніх взаємовідносинах із громадянами та порушення закону зумовили пред'явлення високих вимог до осіб, які підтримують правопорядок. У Кодексі підкреслюється, що ті, хто наділений поліцейськими повноваженнями, зобов'язуються поважати i захищати права людини по відношенню до всіх осіб. Кодекс забороняє застосування катувань та інших форм негуманного або такого, що принижує людську гідність відношення, а також указує, що сила може бути застосована тільки в разі крайньої необхідності. Метою Кодексу є забезпечення «ефективної підтримки етичних норм серед посадових осіб», орієнтація на пріоритет загальнолюдських моральних цінностей (гуманізм, милосердя, справедливість, терпимість та ін.) [3].

$\mathrm{y}$ Кодексі поведінки посадових осіб із підтримання правопорядку міститься звернення до таких моральних кате- горій, як «гідність», «репутація», «людяність», «співчуття», «повага», «моральна поведінка», «моральна відповідальність», а також до понять «приниження людської гідності» та «інші відхилення від гуманістичних норм». Положення Кодексу поведінки посадових осіб із підтримання правопорядку взаємопов'язані з положеннями інших міжнародних організацій.

Установлення партнерських відносин поліціі і суспільства, за яких усі поліцейські, державні структури та населення активно співпрацюють, бачить своїм основним завданням Організація з безпеки і співробітництва в Європі найбільша у світі регіональна організація, що займається питаннями безпеки й об'єднує 57 країн, розташованих у Північній Америці, Європі і Центральній Азії [7].

Співпраця поліції і суспільства має бути спрямована на вирішення проблем забезпечення громадського спокою і правопорядку, захисту основних прав і свобод, особливо життя людини, запобігання і розкриття злочинів, надання сприяння та послуг суспільству 3 метою зниження рівня злочинності [8].

Важливим документом, що встановлює основні правила діяльності поліцейських із забезпечення прав та основних свобод людини, є «Декларація про поліцію», прийнята Парламентською асамблеєю Ради Європи 8 травня 1979 р. У Декларації наголошується, що поліція відіграє життєво важливу роль для держави і членів суспільства; умови, в яких діє поліція, пов'язані з ризиком для працівників і відсутність певних правил поведінки ускладнюють виконання ними своїх обов'язків. Етичні норми, які є обов'язковими для поліцейського та закріплені в «Декларації про поліцію», повинні сприяти тісній співпраці поліції та суспільства [9].

Таким чином, підвищення ефективності взаємодії інститутів громадянського суспільства з поліцією у сфері реалізації правоохоронної функції потребує не тільки вдосконалення його 
правової основи, а й здійснення комплексу заходів, спрямованих на підвищення довіри, взаємної поваги, рівня правової культури, включаючи заходи правової освіти та виховання всіх членів суспільства.

Взаємодія поліції та суспільства здійснюється в тісній співпраці з населенням, територіальними громадами та громадськими об'єднаннями на засадах партнерства i спрямована на задоволення їхніх потреб. Участь громадськості у здійсненні державними органами своїх функцій набуває все більшого значення. Це також відноситься і до участі громадськості в зміцненні правового порядку, попередження злочинності та кримінального правосуддя.

Сьогодні, усвідомлюючи переваги участі громадськості в побудові і зміцненні систем попередження злочинності, значна кількість держав проводить активну політику з установлення партнерських зв'язків з елементами громадянського суспільства (неурядові організації, наукові організації, громадяни та їх об'єднання) [10, с. 55] Розробляються національні і місцеві стратегіі попередження злочинності та забезпечення безпеки, спрямовані на значну кількість представників громадянського суспільства в реформуванні систем кримінального правосуддя, громадського контролю над ефективністю їхньоі роботи і дотриманням прав людини.

Для залучення громадськості в роботу щодо попередження злочинності все частіше використовують нові соціальні медійні засоби інформації (далі - CM3I). Такий підхід містить певний потенціал і можливості для позитивних змін у даній сфері. Водночас, будучи відносно новим, динамічним i децентралізованим явищем, CMЗІ можуть створити певні проблеми в плані безпеки та правосуддя.

Активна участь громадськості в попередженні злочинності ускладнюється низкою проблем. Це пов'язано 3 фрагментарністю знань про механізми та методи участі громадськості в розглянутих сферах, відсутністю традиційних партнерських зв'язків між державою і суспільством, обмеженістю політичної волі, правової свідомості та громадської довіри до діяльності органів державної влади [11, с. 105].

Постійний динамічний розвиток інформаційних технологій, розширення доступу в мережі Інтернет, розвиток соціальних засобів інформаціі, розповсюдження смартфонів та інших технічних засобів зв'язку радикально змінюють спосіб життя, роботу і взаємодію людей.

Правоохоронні органи багатьох держав за допомогою СМЗІ розвивають зв'язки 3 громадськістю і поширюють інформацію 3 метою розслідування та розшуку злочинців. Так, у майбутньому роль СМЗІ в розслідуванні злочинів і розшуку злочинців може ще більше зрости.

Зарубіжні правоохоронні органи використовують у своїй роботі соціальні мережі (наприклад, Facebook), відеохостинг із функціями соціальної мережі YouTube, а також широко використовують Twitter як соціального медійного інструменту для розповсюдження інформації. Наприклад, у Великій Британії та Північній Ірландії система оповіщень через Twitter забезпечує доступ до всієї інформації, що надходить від правоохоронних органів, пожежної служби та інших державних структур.

Поліція Лондона за допомогою Twitter поширює інформацію щодо запобігання крадіжкам особистого майна, а також інформацію про кримінальні розслідування та розшук безвісти зниклих осіб [12, с. 53].

У США департамент поліції Сієтла реалізував у Twitter ініціативу Tweetsby-Beat, яка дає змогу отримувати інформацію про діяльність правоохоронних органів. При цьому в канали не включено інформацію про випадки насильства в сім’і, сексуальні домагання та інші визначені види злочинів. Для уникнення появи людей на місці події повідомлення в Twitter розміщуються із затримкою в одну годину після 
отримання повідомлення про злочин. Також одним із видів використання комунікаційних технологій $€$ розроблення мобільного додатка 3 прив'язкою повідомлень про події 3 картою місцевості.

Соціальні медійні засоби інформації використовуються правоохоронними органами для зміцнення і розвитку взаємодії з місцевим населенням та залученням громадськості до співпраці. Усе більше поширюються випадки, коли СМЗІ використовують із метою розслідування злочинів.

В Україні правоохоронні органи також активно використовують СМЗI. Наприклад, МВС України має облікові записи в усіх соціальних мережах: Facebook, YouTube, Twitter, Instagram, Telegram.

Найближчим часом громадяни зможуть викликати Національну поліцію за допомогою мобільного додатка. Окрім того, в Україні вже запущено сервіс електронних водійських прав у додатку «Дія». Нещодавно представлений додаток «Дія», який нині є електронною базою документів водіїв, уже спробували в роботі понад 310 тис. користувачів [13].

3 огляду на зацікавленість громадськості у використанні різного мобільного контенту, слід уважати, що за допомогою мобільних додатків можливе інформування більш значного кола населення, що сприяє потенційному затриманню розшукуваних злочинців. «Отримання звернень» $є$ безпосереднім каналом зв'язку між населенням та органом державної влади, формуючи один із засобів суспільного контролю над діяльністю поліції.

У цілому можна констатувати користь медійних засобів інформації під час установлення партнерських відносин між правоохоронними органами та громадськістю. Сьогодні для забезпечення участі громадськості в управлінні все частіше використовуються електронні форми участі із застосуванням соціальних медійних засобів інформації, мобільних телефонів та Інтер- нету. Участь громадськості в управлінні державою можна також розширити шляхом удосконалення систем електронного управління, завдяки чому громадяни зможуть розкривати компетентним органам свої думки і надавати пропозиції з потрібних питань.

Велике значення для встановлення своєчасного контакту 3 населенням має ефективна діяльність працівників пресслужби поліції щодо постійного моніторингу та контролю розміщення інформації про правоохоронну діяльності у 3 MI та мережі Інтернет із метою виявлення помилкової інформації. Далеко не завжди критика діяльності поліції $€$ конструктивною, часто 3МI використовують правоохоронну тематику для залучення аудиторії та підвищення своїх рейтингів, недостатньо ретельно перевіряючи матеріали і факти, публікують матеріали, а часом і навмисно спотворюють інформацію.

Підсумовуючи викладене, можна стверджувати, що організація і діяльність поліції на основі взаємодії з громадськістю у сфері забезпечення правоохоронної функції передбачає: реалізацію суспільно орієнтованих принципів; співпрацю поліції з органами державної влади, суспільства і громадянами в процесі забезпечення публічної безпеки та порядку; солідарну відповідальність поліції, інших органів державної влади, суспільства та громадян за стан і рівень забезпечення публічної безпеки та порядку; наявність системи громадського контролю над поліцією. Реалізація принципів відкритості, доступності інформації про діяльність органів поліції, конструктивний діалог поліції і суспільства дадуть змогу підвищити зацікавленість громадян у роботі поліціï, сприятимуть формуванню взаємної довіри і здійсненню співробітництва поліції і суспільства.

У статті розглядаються проблемні питання взаємодії поліції та інститутів громадянського суспільства в Україні. Обтрунтовується найважливіша методологічна роль 
принциипів у проиесі взаємодії. Визначаються основні принципи ефективної організації взаємодії поліції та інститутів громадянського суспільства. Робиться низка конструктивних висновків щодо подальшого поступального розвитку взаємодіi поліції та суспільства.

Методологічна основа дослідження полягає у застосуванні як загальнонаукових прийомів і методів, так i спеціальних наукових методів, вироблених у правознавстві. Під час проведення дослідження особливу роль відіграли такі методи наукового пізнання: діалектичний, історичний, порівняльно-правовий, логічний, метод системно-структурного аналізу. Дослідження будувалося на основі узагальнення $i$ системного аналізу наукових робіт, а також нормативно-правової бази. Вивчення чинної нормативно-правової бази в даній сфері, а також теоретико-методологічних проблем взаємодії поліції та інститутів громадянського суспільства в Україні дає змогу зробити висновок про те, що однією з ї особливостей є причинно-наслідкова зумовленість. Кожна із взаємодіючих сторін виступае як причина іншої $i$, як наслідок, одночасного зворотного впливу протилежної сторони.

Відзначається, що будь-яка взаємодія поліції та інститутів громадянського суспільства носить змінний характер та ї якість залежить від рівня розвитку суспільства $i$ держави. Проблеми взаємодії поліції та суспільства у сфері реалізації правоохоронної функції визначають необхідність вивчення особливостей взаємодії поліиї та інститутів громадянського суспільства з метою підвищення ефективності функціонування органів полічї $і$ свідчать про необхідність науково-практичних рекомендаизій.

У роботі наголошуеться на необхідності впровадження в діяльність поліції використання соиіальних медійних засобів інформації для зміцнення $i$ розвитку взаємодіі $з$ місцевим населенням та залученням громадськості до співпраці в процесі реалізації правоохоронної функції.

Ключові слова: взаємодія, поліція, правоохоронна функція, громадськість, суб'єкти взаємодії, принципи взаємодіï, громадський контроль, зарубіжний досвід.

Kubaienko A. The interaction of the police and institutions of civil society in law enforcement activities

In this article the author has undertaken an attempt to consider a number of problem issues dealing with the notions, principles and forms of interaction between the police and institutions of civil society in Ukraine. The author studies the interrelation of the types of interaction. The author of the article provides the foundation of the most important methodological role of the principles during the interaction process. There have been drawn a number of constructive conclusions regarding further progressive development of such interaction.

The methodological foundation of the research is presented by both general scientific methods and ways and also by special scientific methods developed in the science of law. While carrying out the research the following methods of scientific cognition have played a special role: the dialectical method, the historical method, the comparative legal, the logical method and the method of comprehensive structural analysis. The research has been performed on the basis of generalization and comprehensive analysis of scientific works as well as on the basis of the analysis of the regulatory legal base. The study of the acting regulatory legal base in this sphere as well as the study of theoretical and methodological problems of the interaction between the police and institutions of civil society in Ukraine allows making the conclusion that one of the peculiarities of this interaction is the cause-and-effect predicament. 
Each of the interacting sides appears as the cause of the other one and as the consequence of the simultaneous influence of the opposite side.

The author notes that any interaction between the police and civil society institutions is variable and its quality depends on the level of development of society and the state. Problems of interaction between the police and society in the implementation of law enforcement determine the need to study the interaction of the police and institutions of civil society in order to improve the efficiency of police bodies and indicate the need for scientific and practical recommendations.

The article emphasizes the need to introduce the use of social media in the police to strengthen and develop interaction with the local population and involve the public in cooperation in the implementation of law enforcement function.

Key words: interaction, police, law enforcement activity, community, subjects of the interaction, principles of interaction, public control, foreign experience.

\section{Література}

1. Безпалова O.I. Методологічні засади адміністративно-правового механізму реалізаціі правоохоронної функиї держави. Development and modernization of the legal systems of Eastern Europe: experience of Poland and prospects of Ukraine. 2017. Vol. 2. P. 57-79.

2. Проневич О.С. Проактивна діяльність поліції (міліціі) як складова сучасної парадигми охорони правопорядку. Форум права. 2011. № 3. С. 639-643.

3. Юнін О.С. Поліція в системі державних органів та забезпечення громадської безпеки. Держава та регіони. Серія «Право». 2013. № 1(39). С. 59-63.

4. Nizhnik N.S. Police and civil society institutions: search for a vector of interaction in the field of combating crime. International Scientific Conference "Archibald Reiss Days» (2017, Beograd): Thematic Conference Proceedings of International Significance. Vol. 2. S. 244-245.

5. Кодекс поведінки службовців органів правопорядку, затверджений Резолюијєю Генеральної Асамблеї ООН № 34/169 від 17 грудня 1979 p. URL : https: / / www.un.org / ru/documents / decl_conv/conventions / code_of_conduct.shtml

6. Руководящие принципь для эффективного осуществления Кодекса поведения должностных лии по поддержанию правопорядка (приняты 24 мая 1989 г. Резолюизией 1989/61 на 15-м пленарном заседании Экономического и Социального Совета OOH). URL : http://ukrprison.org.ua/ international_documents / 1203409773.

7. Final act of the 1st CSCE Summit of Heads of State or Government. URL : http: / / www.osce.org / node / 39501.

8. Second CSCE Summit of Heads of State or Government, Paris, 19-21 November 1990. Supplementary document to give effect to certain provisions contained in the Charter of Paris for a New Europe. URL: http: / / www. osce.org / node/39516.

9. Резолюція № 690 (1979) Парламентської асамблеї Ради Європи "Декларація nро поліuію». URL : https://zakon.rada. gov.ua/laws/show/994_803.

10. Медведенко С.В. Форми взаємодії громадськості в правоохоронній діяльності. Стан та перспективи розвитку адміністративного права України : матеріали V Міннародної науково-практичної Інтернет-конференції, м. Одеса, 25 жовтня 2018 p. Одеса, 2018. C. 54-58.

11. Субота С.І. Сучасні наукові уявлення щодо взаємодії громадянського суспільства i поліцейських структур. Право і Безпека. 2015. № 3. C. 103-108.

12. Кожухар О.В. Удосконалення взаємодї поліції з інститутами громадянського суспільства (на основі міжнародного досвіду). Наука і правоохорона. 2017. № 4. C. 52-57.

13. МВС працюе над мобільним додатком для виклику поліміï. URL : https:// mvs.gov.ua/ua/news/28781. 